\title{
Blood Protein Measurement
}

National Cancer Institute

\section{Source}

National Cancer Institute. Blood Protein Measurement. NCI Thesaurus. Code C92745.

A quantitative measurement for assessing the amount of protein present in a blood sample. 